\section{Association of Enzyme Inhibition with Methods of Museum Skin Preparation}

BioTechniques 22:928-934 (May 1997)

\begin{abstract}
Enzyme inhibition is commonly encountered when using molecular biological techniques on museum-prepared animal skin samples, and this problem is exacerbated by a lack of information on how particular skins have been prepared for preservation. This report: (i) demonstrates that while some methods of museum preparation inhibit both proteinase $K$ digestion and the $P C R$, others do not; (ii) describes a change in buffer conditions that reduces proteinase $K$ enzyme inhibition during tissue digestion; and (iii) uses electron-dispersive $X$-ray microanalysis (EDXA) to show that the preparation methods for museum-preserved skin are often more complex than the treatment description provided with samples and also suggests that some of these descriptions are incorrect.
\end{abstract}

\section{INTRODUCTION}

DNA from museum-preserved animal pelts is a valuable resource in evolutionary studies and has been used to elucidate the phylogenetic relationships between present day and extinct taxa (3), provide a temporal component to studies of genetic change $(12,13)$ and facilitate studies of the genetic variation of endangered taxa (9). Despite these successes, the extraction and amplification of DNA from museum-preserved tissue cannot be considered routine and it is likely that this is, in part, caused by the different preparation methods used to preserve animal skins (2). Different preparation methods may result in the inhibition of those enzymes used to digest tissue or amplify DNA, or even the destruction of the DNA within a sample. These problems are exacerbated by poor records on how particular skins have been preserved, which has hampered attempts to study the relationship between successful polymerase chain reaction (PCR) am-

Table 1. Method of Preservation for Museum Skin Samples and the Elements Detected

\begin{tabular}{|lll|}
\hline $\begin{array}{l}\text { Sample } \\
\text { Number }\end{array}$ & $\begin{array}{l}\text { Information Provided } \\
\text { with Sample }\end{array}$ & $\begin{array}{l}\text { Elements Found } \\
\text { in Sample }\end{array}$ \\
\hline Control & $\begin{array}{l}\text { Freeze-dried } \\
\text { Mammal (mouse), 1995 }\end{array}$ & O,P,S,Cl,K \\
Sample 1 & $\begin{array}{l}\text { Dried } \\
\text { Mammal (domestic cat), 1972 }\end{array}$ & O,P,S,Cl,K \\
Sample 2 & $\begin{array}{l}\text { Dried } \\
\text { Mammal (feral cat), 1973 }\end{array}$ & O,Na,Mg,S,Cl \\
Sample 3 & $\begin{array}{l}\text { Arsenic-treated } \\
\text { Avian (gosander), late 1800s }\end{array}$ & O,P,S,Cl,K,Cu \\
Sample 4 & $\begin{array}{l}\text { Arsenic-treated } \\
\text { Avian (little auk), 1895 }\end{array}$ & O,Na,S,Cl,Ca,Cr \\
Sample 5 & $\begin{array}{l}\text { Tanned } \\
\text { Mammal (primate), late 1800s }\end{array}$ & $\mathrm{Na}, \mathrm{Al}, \mathrm{S}, \mathrm{Cl}$ \\
Sample 6 & $\begin{array}{l}\text { Tanned } \\
\text { Mammal (kus kus), 1994 }\end{array}$ & $\mathrm{O}, \mathrm{Mg}, \mathrm{Si}, \mathrm{S}, \mathrm{Cl}, \mathrm{K}, \mathrm{Ca}$ \\
Sample 7 & $\begin{array}{l}\text { Borax-treated } \\
\text { Avian (blackbird), 1981 }\end{array}$ & $\mathrm{O}, \mathrm{Mg}, \mathrm{Al}, \mathrm{S}, \mathrm{Ca}$ \\
Sample 8 & $\begin{array}{l}\text { Borax-treated } \\
\text { Avian (magpie), 1981 }\end{array}$ & $\mathrm{O}, \mathrm{Al}, \mathrm{Si}, \mathrm{S}, \mathrm{Cl}, \mathrm{K}, \mathrm{Ca}$ \\
$\begin{array}{l}\text { Recorded sample treatment, origin, date of samples and chemical elements } \\
\text { present on skin as determined using EDXA. The precise treatment method of } \\
\text { museum samples is difficult to determine from records. Samples fall into the fol- } \\
\text { lowing categories: dried samples were salt (unknown type)-dried; arsenic sam- } \\
\text { ples were preserved using arsenical soap; tanned samples were subject to un- } \\
\text { known tanning processes; borax samples were preserved using borax paste. }\end{array}$ \\
\hline
\end{tabular}

plification and the preparation methods used in museum skin preservation.

This paper describes work to test: $(i)$ whether the method of museum skin preparation affects the efficiency of proteinase $\mathrm{K}$ digestion and (ii) whether the method of museum skin preparation affects the amplification of DNA using the PCR.

\section{MATERIALS AND METHODS}

Duplicate $12-\mathrm{mm}^{2}$ samples were taken from eight museum-prepared mammalian and avian skins using a cork borer. The samples ranged in date from the late 19th century to 1994 , and museum records suggest that they were preserved using either drying, tanning or treatment with arsenic or borax, as indicated in Table 1. A fresh freezedried skin from a laboratory mouse was used as a control.

One of the duplicate samples was soaked in $1 \mathrm{~mL}$ water at $55^{\circ} \mathrm{C}$ for $48 \mathrm{~h}$, and the rinse water was subsequently used to assay for inhibition of both proteinase $\mathrm{K}$ digestion and PCR. The other duplicate was used to determine the elemental composition of the skin using electron-dispersive X-ray microanalysis (EDXA).

The digestion inhibition assay involved incubating $100 \mu \mathrm{g}$ ovalbumin (Sigma Chemical, St. Louis, MO, USA) with $100 \mu \mathrm{g}$ proteinase K (Boehringer Mannheim, Mannheim, Germany) at $55^{\circ} \mathrm{C}$ in $1 \mathrm{~mL}$ of either water or $10 \mathrm{mM}$ Tris-HCl buffer, $\mathrm{pH} 8.0$ (Sigma Chemical). Both buffer conditions have previously been used to digest museum samples $(4,13)$, and the large amount of enzyme is typical of that used in previous work on museum tissue. Duplicate $100-\mu \mathrm{L}$ samples of the digestion mixture were removed after $0,10,30$ and 60 min of incubation, and the reaction was terminated by the addition of $700 \mu \mathrm{L}$ of $70 \mathrm{mM}$ trichloroacetic acid (Sigma Chemical). The total protein remaining after digestion was estimated using the Bradford method (1) by adding $200 \mu \mathrm{L}$ of a concentrated 
dye reagent (Bio-Rad, München, Germany) to the duplicate terminated protein digestions and measuring the absorbance at $595 \mathrm{~nm}$ after $5 \mathrm{~min}$. Since it was important to keep within the linear range of the protein assay, the large amount of proteinase K (enzyme) used in these digestions constrained the amount of ovalbumin (substrate) added, resulting in the catalysis of ovalbumin and autocatalysis of proteinase $\mathrm{K}$. Absorbencies were therefore converted into the percentage of total protein remaining after incubation, by calculating the ratio of the absorbance at 10,30 and $60 \mathrm{~min}$ compared to that at $0 \mathrm{~min}$. This overcame the need to calibrate for the mass of protein remaining and also compensated for possible colorimetric interference due to the different solutes in the rinse waters. Results were compared graphically and analyzed using analysis of variance (11).

The PCR inhibition assay involved the amplification of a 369-bp fragment of the lac $Z^{\prime}$ gene from the double-

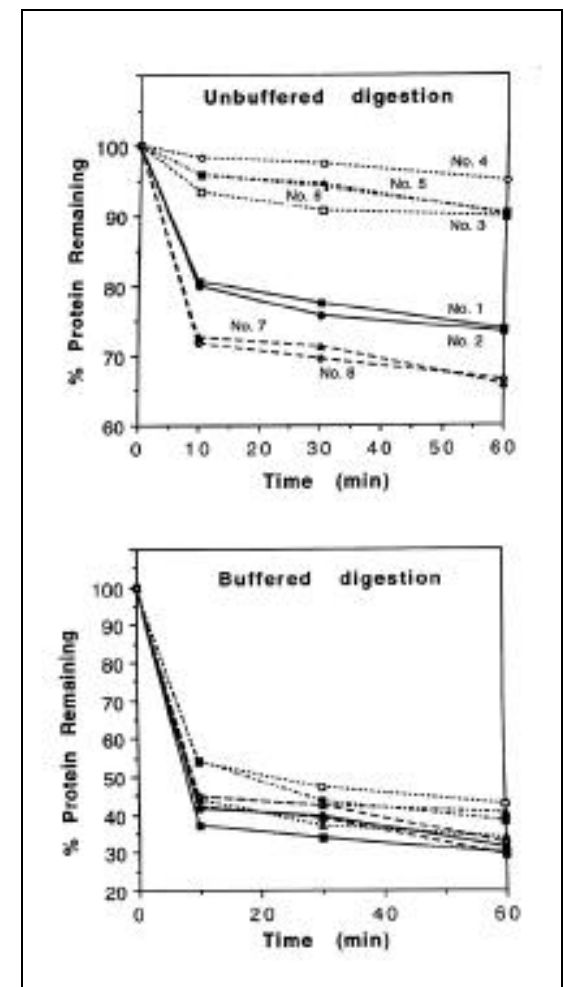

Figure 1. Percentage protein digestion in the presence of rinse waters from museum-prepared skin samples in buffered and unbuffered reaction conditions. Information on the method of preparation and the chemical element composition for each sample is presented in Table 1. 
stranded phagemid pTZ19R (8) using the primers $5^{\prime}$ TTGCCGATTTCGGCCTATT3' and 5'TCCGGCTCGTATGTTGTGT3' in the presence of the rinse waters. This approach ensures that differences in DNA amplification between samples can be ascribed to the effect of the rinse waters, rather than the presence of different amounts of endogenous DNA. PCR was performed in $50-\mu \mathrm{L}$ reactions comprising final concentrations of $1 \mu \mathrm{M}$ of each primer, 0.2 $\mathrm{mM}$ of each dNTP, $20 \mathrm{mM}$ Tris- $\mathrm{HCl}$, $50 \mathrm{mM} \mathrm{KCl}$ (all from Life Technologies, Paisley, Scotland, UK), $2.5 \mathrm{mM}$ $\mathrm{MgCl}_{2}$ (Sigma Chemical), and containing $20 \mu \mathrm{L}$ of the appropriate rinse water, either $1.6 \times 10^{5}$ or $1.6 \times 10^{8}$ copies of the double-stranded pTZ19R and $1 \mathrm{U}$ Taq DNA Polymerase (Life Technologies). Reaction conditions comprised an initial denaturation at $94^{\circ} \mathrm{C}$ for $60 \mathrm{~s}$ followed by 30 cycles of denaturation at $94^{\circ} \mathrm{C}$ for $30 \mathrm{~s}$, annealing at $55^{\circ} \mathrm{C}$ for 30 $\mathrm{s}$ and extension at $72^{\circ} \mathrm{C}$ for $30 \mathrm{~s}$ and terminated after a final extension of $120 \mathrm{~s}$. Eight microliters of the resulting reactions were run on a $1.5 \%$ agarose gel (Boehringer Mannheim) containing 0.5 $\mu \mathrm{g} / \mathrm{mL}$ ethidium bromide (Sigma Chemical) at $5 \mathrm{~V} / \mathrm{cm}$ for $1 \mathrm{~h}$ and visualized under UV light at $302 \mathrm{~nm}$.

The elemental composition of museum skin samples was assessed using EDXA (10). The rationale behind using EDXA is that in certain cases it may be possible to relate the presence of chemical elements in museum-preserved skin samples to the substances used to treat the skin. Uncoated samples were examined using a Jeol JSM 840 Scanning Electron Microscope with a Link 860 II Analyser (Tokyo, Japan) using a $\mathrm{Si}(\mathrm{Li}) \mathrm{X}$-ray detector fitted with an atmospheric detector allowing the detection of chemical elements with an atomic number of 8 and upwards.

\section{RESULTS AND DISCUSSION}

The results of the proteinase $\mathrm{K}$ digestion assay, presented in Figure 1, illustrate the change in the amount of undigested protein (which includes ovalbumin and proteinase $\mathrm{K}$ ) after incubation over $1 \mathrm{~h}$ for both buffered and unbuffered digestion conditions, in the presence of the rinse waters from each skin. The results suggest that there are overall differences in the efficiency of proteinase $\mathrm{K}$ digestion between the different samples and that these differences are most marked in the unbuffered reaction conditions, where samples can be clearly divided into those that inhibit digestion and those that do not. A statistical analysis supports these observations. Differences in the amount of digestion due to different samples are statistically very highly significant $\left(F_{7,21}=17.7 * * *\right)$, as is the interaction between samples and buffer conditions $\left(F_{7,21}=7.6^{* * *}\right)$. Furthermore, the reduction in the variation between samples for protein digestion in the buffered compared to the unbuffered digestion conditions is statistically significant $\left(F_{7,7}=5.9^{*}\right)$. The distinction between buffer conditions is important since several protocols have been used to extract DNA from museum preserved tissue $(4,6,7,13)$, and these results suggest that some of these methods are more sensitive to the inhibitory effects of museum preservation than others.

The results of the PCR inhibition assay, presented in Figure 2, illustrate the amplification of both $1.6 \times 10^{8}$ and 1.6 $\times 10^{5}$ copies of added template DNA in the presence of the rinse water from each of the samples. Template DNA at

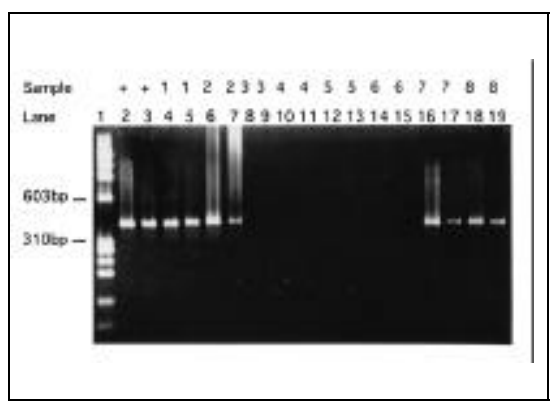

Figure 2. PCR amplification of a 369-bp fragment of the lac $Z^{\prime}$ gene from $p T Z 19 R$ in the presence of rinse water from museum-prepared skin samples. Lane 1 contains $1 \mu \mathrm{g}$ $\phi X 174 / H a e I I I ;$ lanes 2, 4, 6, 8, 10, 12, 14, 16 and 18 contain PCR products using $1.6 \times 10^{8}$ template fragments; lanes $3,5,7,9,11,13,15,17$ and 19 contain PCR products using $1.6 \times 10^{5}$ template fragments. In addition, the PCR products in lanes 2 and 3 contain the control sample; lanes 4 and 5, sample 1; lanes 6 and 7, sample 2; lanes 8 and 9 , sample 3; lanes 10 and 11, sample 4; lanes 12 and 13, sample 5; lanes 14 and 15, sample 6; lanes 16 and 17, sample 7; lanes 18 and 19 , sample 8 . both quantities was amplified in samples $1,2,7$ and 8 , whereas there was no evidence of template amplification for samples 3, 4, 5 and 6. This suggests that while some museum skin treatments do have an inhibitory effect on PCR, others do not. The pattern of inhibition is the same as that for the proteinase $\mathrm{K}$ digestion assay in that those samples that inhibit protein digestion also inhibit PCR amplification. These results suggest that enzyme inhibition is a consequence of the presence of water-soluble inorganic and/or organic substances used in the treatment of museum skin during preservation procedures.

Discussions with taxidermists and reference to manuals describing the treatment of skins $(5,14)$ suggest that a wide range of chemical compounds have been used to treat skins. Preservatives include arsenic trioxide $\left(\mathrm{As}_{2} \mathrm{O}_{3}\right.$ and $\mathrm{As}_{4} \mathrm{O}_{6}$ ), alum $\left(\mathrm{AlK}\left(\mathrm{SO}_{4}\right)_{2} \cdot 12 \mathrm{H}_{2} \mathrm{O}\right)$, borax $\left(\mathrm{Na}_{2} \mathrm{~B}_{4} \mathrm{O}_{7} \cdot 10 \mathrm{H}_{2} \mathrm{O}\right)$, saltpeter $\left(\mathrm{KNO}_{3}\right)$, salt $(\mathrm{NaCl})$ and chemical tanning agents such as chromium, aluminum or zirconium salts. However, the treatment of skins can also involve the use of a wide range of substances for the subsequent drying, such as dettol, phenol and soap powder during the initial washing and cleaning of skins, and sawdust, corn flour and magnesium carbonate. EDXA was therefore used to provide further information on the method of museum skin treatment by analyzing the inorganic elements present on the skin.

Twelve inorganic elements were detected on the skin samples (Table 1). Five of these: oxygen, phosphorus, sulfur, chlorine and potassium, were observed in the untreated mouse control skin and are assumed to reflect the composition of untreated skin. On experimental samples, the remaining seven: sodium, magnesium, aluminum, silica, calcium, chromium and copper are most likely the consequence of museum preparation. The distribution of the chemical elements does not always correspond to the pattern of enzyme inhibition described earlier. This may be because inhibition is caused by the inorganic chemical compounds and how they are applied, rather than by the presence of the single chemical elements, or due to the use of inhibitory 
organic compounds, which cannot be detected using this technology.

Although EDXA cannot be used to determine the method of museum skin preparation unambiguously, the method does provide information independent of museum records. The presence of magnesium on samples 2, 6 and 7 is consistent with the use of magnesium carbonate, and the presence of sodium on samples 2, 4 and 5 is consistent with the use of salt. The results of this study also suggest that even when the treatment of samples is described in museum records, the actual treatment is often very much more complex. Hence, the borax-treated samples ( 7 and 8 ), both of which are recently preserved, contain a range of elements including magnesium, aluminum, calcium and silicon, suggesting that preservation with borax is only a part of the treatment. Results from EDXA also suggest that the method of treatment described by museums is sometimes incorrect; for example, neither of the "arsenictreated" samples contained arsenic. Both of these samples are poorly documented, being from the late 19th century, and the most likely explanation is that the samples were not actually prepared using arsenic. Indeed, the presence of copper on sample 3 is consistent with the use of a copper compound in one of the treatment recipes, and a prominent peak of chromium on sample 4 suggests that it was probably tanned using chromium salts.

The data presented in this report suggest that different methods of preserving skin do have an effect on both proteinase $\mathrm{K}$ and PCR inhibition. A knowledge of which preparation methods result in enzyme inhibition would allow for the more efficient utilization of museum-preserved tissues and the development of methods for removing inhibitory compounds.

\section{REFERENCES}

1.Bradford, M. 1976. A rapid and sensitive method for the quantification of microgram quantities of protein utilizing the principle of protein-dye binding. Anal. Biochem. 72:248254.

2.Cooper, A. 1994. DNA from museum specimens, p. 149-165. In B. Herrmann and S. Hummel (Eds.), Ancient DNA. Springer-Verlag, New York.

3.Cooper, A., C. Mourer-Chauvire, G.K. Chambers, A. von Haeseler, A.C. Wilson and S. Pääbo. 1992. Independent origins of New Zealand moas and kiwis. Proc. Natl. Acad. Sci. USA 89:8741-8744.

4.Ellegren, H. 1991. DNA typing of museum birds. Nature 354:113.

5.Hasluck, P.N. 1901. Taxidermy. Cassell and Company, London.

6.Kocher, T.D., W.K. Thomas, A. Meyer, S.V. Edwards, S. Pääbo, F.X. Villablanca and A.C. Wilson. 1989. Dynamics of mitochondrial DNA evolution in animals: amplification and sequencing with conserved primers. Proc. Natl. Acad. Sci. USA 86:6196-6200.

7.Leeton, P., L. Christidis and M. Westerman. 1993. Feathers from museum bird skins-a good source of DNA for phylogenetic studies. 
The Condor 95:465-466.

8.Mead, D.A., E. Szczesna-Skorupa and B. Kemper. 1986. Single-stranded DNA 'blue' T7 promoter plasmids: a versatile tandem promoter system for cloning and protein engineering. Protein Eng. 1:67-74.

9.Roy, M.S., D.J. Girman, A.C. Taylor and R.K. Wayne. 1994. The use of museum specimens to reconstruct genetic variability and relationships of extinct populations. Experientia 50:551-557.

10.Scott, V.D. and G. Love. 1983. Quantitative Electron Probe Microanalysis. Ellis Horwood, New York.

11.Snedecor, G.W. and W.G. Cochran. 1980. Statistical Methods, 7th Ed. The Iowa State University Press, Ames.

12.Taylor, A.C., W.B. Sherwin and R.K. Wayne. 1994. Genetic variation of microsatellite loci in a bottlenecked species: the Northern hairy-nosed wombat, Lasiorhinus krefftii. Mol. Ecol. 3:277-299.

13.Thomas, W.K., S. Pääbo, F.X. Villablanca and A.C. Wilson. 1990. Spatial and temporal continuity of Kangaroo Rat populations shown by sequencing mitochondrial DNA from museum specimens. J. Mol. Evol. 31:101-112.

14.Wagstaffe, R. and J.H. Fidler. 1968. The Preservation of Natural History Specimens, Vol. 2. H.F. \& G. Witherby, London.

We thank Drs. Clemency Fisher (Liverpool Museum) and Andrew Kitchener (National Museums of Scotland) who provided samples for this work. We are also indebted to Mr. David Mellow (Liverpool John Moores University) for performing the EDXA, to Mr. George McInnes (Liverpool Museum) for valuable discussions and to two anonymous referees for helpful comments. This work was funded by the Leverhulme Trust and Trustees of the National Museums \& Galleries on Merseyside. Address correspondence to Mark S. Willcox, School of Biological \& Earth Sciences, Liverpool John Moores University, Byrom St., Liverpool L3 3AF, England, UK. Internet: m.willcox@livjm.ac.uk

Received 13 May 1996; accepted 21 October 1996.

L. Malcolm Hall, Mark S. Willcox ${ }^{1}$ and David S. Jones University of Liverpool

${ }^{1}$ John Moores University Liverpool, England, UK

\section{Detection of Mycoplasma Infection of Mammalian Cells}

BioTechniques 22:934-936 (May 1997)

\section{ABSTRACT}

Mycoplasma infection was detected in cultures of COS cells with a novel, simple assay that detects the conversion of arginine to citrulline by the enzyme, arginine deiminase, specific to all species of mycoplasma. Transfection of COS cells was inhibited in mycoplasma-infected cells, a phenomenon that was readily reversed by treatment with a mycoplasma removal agent. Cultures of cells used for transfection should be regularly monitored for evidence of mycoplasma by assay of arginine deiminase activity or by other methods.

\section{INTRODUCTION}

Mycoplasma are parasitic prokaryotic organisms that reside in endosomes of mammalian cells. They are incapable of peptidoglycan synthesis and thereby lack a rigid cell wall, which makes them resistant to penicillin-type antibiotics that are often added to cell culture medium (8). The effects of mycoplasma infection of mammalian cells varies depending on the species of mycoplasma, the degree of infection and the cell type. More specific effects of infection include preferential incorporation of nucleic acid precursors into mycoplasmal cells at the expense of host cells (5), secretion of collagenase by the host cell (7), interference with signal transduction (3), altered levels of $\mathrm{IgE}$ and transferrin receptors in basophilic leukemia cells (2) and increased secretion of soluble interleukin-2 receptor (6). Most, if not all, mycoplasma utilize arginine as an energy source mediated by the enzyme (Enzyme Commission No. EC3.5.3.6) arginine deiminase $(9,10)$. A side effect of the metabolism of arginine by this organism is the production of ammonia along with citrulline. It has been suggested that arginine deiminase activity maintains endosomes at a pH that blocks cycling through the lysosomal pathway.
Thus, a major deleterious effect of mycoplasma may be interference with normal vesicular trafficking in cells. Most transfection methods involve endocytosis of plasmid DNA complexed with various agents, such as DEAE-dextran, $\mathrm{CaPO}_{4}$, lipids, and so on. This is a particularly important issue with respect to transient transfections.

\section{MATERIALS AND METHODS}

Growth and transfection of COS cells was performed exactly as described (4). COS cells were stained with the 4',6-diamidino-2-phenylindole (DAPI) according to the manufacturers instructions (Sigma Chemical, St. Louis, MO, USA). Briefly, cells were washed with methanol followed by the addition of $10 \mathrm{mg} / \mathrm{mL}$ DAPI in methanol, incubated for $15 \mathrm{~min}$ at room temperature, washed twice with methanol and visualized with a fluorescent microscope using a $40 \times$ oil immersion objective. Mycoplasma removal agent was obtained from ICN Biomedicals (Costa Mesa, CA, USA) and was used as directed.

\section{RESULTS AND DISCUSSION}

We have observed that, in some cultures of COS cells, transfection efficiency was drastically decreased, and the cells grew slowly. However, it was otherwise not obvious that the cells were not healthy. Apart from the slow growth, the cells plated efficiently and maintained a flattened fibroblastic morphology. Since we suspected mycoplasma infection, we investigated this possibility by assaying COS cells for arginine deiminase activity by means of a novel assay method. The assay is very similar to a routine assay used in this laboratory for nitric oxide synthase and depends upon the conversion of radioactive arginine (which is charged) to citrulline (which is uncharged) (1). The simplicity of the citrulline assay allows hundreds of enzyme assays to be done in a few hours. A 10-cm dish of COS cells were prepared by brief sonication $(10 \mathrm{~s})$ in $2 \mathrm{~mL}$ phosphate-buffered saline (PBS) with a probe sonicator. For routine assays, $25 \mu \mathrm{L}$ of cell extract 